\title{
Balancing Porosity and Mechanical Properties of Titanium Samples to Favor Cellular Growth against Bacteria
}

\author{
Ana Civantos ${ }^{1, *}$, Ana M. Beltrán ${ }^{2, * \mathbb{D}}$, Cristina Domínguez-Trujillo ${ }^{2}$, Maria D. Garvi ${ }^{3}$, \\ Julián Lebrato $^{3}{ }^{(D)}$, Jose A. Rodríguez-Ortiz ${ }^{2} \mathbb{D}$, Francisco García-Moreno ${ }^{4}$, \\ Juan V. Cauich-Rodriguez ${ }^{5}$, Julio J. Guzman ${ }^{2}$ and Yadir Torres ${ }^{2}$ (D) \\ 1 Micro and Nanotechnology Laboratory, University of Illinois at Urbana-Champaign, Urbana, IL 61801, USA \\ 2 Departamento de Ingeniería y Ciencia de los Materiales y del Transporte, Escuela Politécnica Superior, \\ Universidad de Sevilla, Virgen de África 7, 41011 Sevilla, Spain; cdominguez10@us.es (C.D.-T.); \\ jarortiz@us.es (J.A.R.-O.); juguzpe@gmail.com (J.J.G.); ytorres@us.es (Y.T.) \\ 3 Grupo TAR, Escuela Politécnica Superior, Universidad de Sevilla, 41004 Sevilla, Spain; mgarvi@us.es (M.D.G.); \\ grupotar@us.es (J.L.) \\ 4 Institute of Applied Materials, Helmholtz-Zentrum Berlin für Materialien und Energie, Hahn-Meitner-Platz 1, \\ 14109 Berlin, Germany; garcia-moreno@helmholtz-berlin.de \\ 5 Unidad de Materiales, Centro de Investigación Científica de Yucatán A. C., 97205 Mérida, Yucatán, Mexico; \\ jvcr@cicy.mx \\ * Correspondence: ancife@illinois.edu (A.C.); abeltran3@us.es (A.M.B.)
}

Received: 6 September 2019; Accepted: 22 September 2019; Published: 24 September 2019

\begin{abstract}
Two main problems limit the success of titanium implants: bacterial infection, which restricts their osseointegration capacity; and the stiffness mismatch between the implant and the host cortical bone, which promotes bone resorption and risk of fracture. Porosity incorporation may reduce this difference in stiffness but compromise biomechanical behavior. In this work, the relationship between the microstructure (content, size, and shape of pores) and the antibacterial and cellular behavior of samples fabricated by the space-holder technique $\left(50 \mathrm{vol} \% \mathrm{NH}_{4} \mathrm{HCO}_{3}\right.$ and three ranges of particle sizes) is established. Results are discussed in terms of the best biomechanical properties and biofunctional activity balance (cell biocompatibility and antibacterial behavior). All substrates achieved suitable cell biocompatibility of premioblast and osteoblast in adhesion and proliferation processes. It is worth to highlighting that samples fabricated with the 100-200 $\mu \mathrm{m}$ space-holder present better mechanical behavior-in terms of stiffness, microhardness, and yield strength—which make them a very suitable material to replace cortical bone tissues. Those results exposed the relationship between the surface properties and the race of bacteria and mammalian cells for the surface with the aim to promote cellular growth over bacteria.
\end{abstract}

Keywords: bone implant; porous titanium; cellular adhesion; bacteria colonization; osseointegration

\section{Introduction}

Longer life expectancy, traumas, and congenital diseases have led to an increase in the use of implants. Bone metal implants are usually made of commercially pure titanium (c.p. Ti) or based on Ti alloys owing to its biocompatibility and mechanical behavior [1]. C.p. Ti has a Young's Modulus of 100-110 GPa, which is higher than cortical bone (20-25 GPa), causing stress shielding phenomena and bone resorption [2]. This problem can be solved using porous material instead of fully-dense one [3-6]. However, in order to achieve a biomechanical balance (stiffness vs. mechanical strength) of the bone tissue to be replaced, an adequate porosity (in terms of size, shape, and distribution of the pores) is 
required. Up to 34 processing routes to fabricate porous materials have been already reported [7-10]. Among them, the use of space-holders stands out. This technique uses particles—such as salt [11,12], sugar [13], ammonium bicarbonate [14], or magnesium [15] — to reproduce a bone-like porosity structure in which the space-holder particles can be removed by thermal process or dissolution. This step can be performed before or during the sintering process. The particle size and morphology are key factors in the design of the pore structure. One remarkable advantage is that the space-holder is a cost-effective and non-toxic method, which does not release any toxic agent which could affect cellular and bacterial behavior.

On the other hand, several authors have reported that surface properties such as the topography, roughness, chemistry, and free energy of metallic based biomaterials have a strong influence on the initial adhesion and early differentiation of osteoblast cells [16,17]. In 1987, Gristina was the first author to use the term "the race" for the surface, regarding the competition established between bacteria and cells for the biomaterial surface [18]. Also, Gristina remarked that if bacteria attached and colonize faster than osteoblast cells-i.e., bacteria wins the race-an infection will take place, which will be almost impossible to remove. This effect is due to the fast process of bacteria to excrete extracellular polymeric substances (EPS) once they are attached. The size is one the most highlighted difference: osteoblasts are bigger in size, ranging from $20-30 \mu \mathrm{m}$, bacteria such as Escherichia coli (E. coli) or Staphylococcus aureus (the most common bacteria presented in titanium dental implants) are around 1-2 $\mu \mathrm{m}$ in length [19]. The stiffness, surface topography (i.e., roughness) and surface chemistry can be tailored in order to promote an advanced cell adhesion process. It has been described the high stiffness behavior of bacteria compared to osteoblast cells, which can be a potential factor in bacteria adhesion and colonization [20]. However, the adhesion mechanisms and the proliferation rate of bacteria are key factors that favor bacteria in the race for the surface. Filia, pili, and the expression of EPS, which constitute the biofilm formation, are some of the mechanisms that participate in the interactions between bacteria and the surface. This EPS covers and protects the bacteria under a biofilm. In this scenario, bacteria becomes more resistant and the antibiotic treatment usually has no effect. On the other hand, osteoblast cells require a more complex mechanism involving integrin receptors and proteins to develop focal adhesion (FA) points. The FA are based of filopodia and lamellipodia cytoplasmatic projections that control and regulate cell to cell interactions and cell surface as well. Therefore, the control of surface properties may reduce or avoid the bacteria attachment resulting in the successful application of the implant on bone regeneration [19].

In a previous work, we reported the manufacture of porous substrates by the space-holder technique which showed a decrease of bacteria attachment [21]. However, the vast majority of studies which focus on Ti implants made use of either bacteria or celld independently and, thus made it difficult to analyze of what type of surface properties may enhance infections and/or osseointegration. Therefore, here we report for the first time the behavior of bacteria and two murine cell lines (myoblast and osteoblast) on c.p. Ti porous substrates with the aim to design a porous implant able to promote bone regeneration and avoid bacterial infections. In this context, this work examines a detailed study of the influence of microstructural characteristics (size, shape, area, and porosity roughness) on the macro and micro-mechanical behavior, as well as the response of the material in the presence of eukaryotic cell cultures (C2C12-GFP and MC3T3E1) and E. coli strain bacteria (Gram-negative bacteria).

\section{Materials and Methods}

\subsection{Fabrication of Ti substrates}

The blends of medical grade 4 c.p. Ti were supplied by SE-JONG (Materials Co. Ltd. Gojan-dong Korea). Fully-dense c.p. Ti samples were obtained by conventional powder technology (PM), while porous substrates were fabricated using space-holder technique (50 vol $\% \mathrm{NH}_{4} \mathrm{HCO}_{3}$ and different ranges of particle size: $100-200 \mu \mathrm{m}, 250-355 \mu \mathrm{m}$, and 355-500 $\mu \mathrm{m})$. The green samples were produced by pressing at $800 \mathrm{MPa}$ by means of an Instron 5505 universal testing machine (Instron, High Wycombe, 
UK). Then, the spacer was thermally removed (firstly at $60^{\circ} \mathrm{C}$ and, then at $110^{\circ} \mathrm{C}$ under low vacuum conditions), both stages of the thermal treatment are carried out for 10-12 $\mathrm{h}$ and low vacuum conditions of $10^{-2} \mathrm{mbar}$ ). Subsequently, the samples (porous and fully-dense) were sintered in a ceramic tubular furnace during $2 \mathrm{~h}$ at $1250{ }^{\circ} \mathrm{C}$ under high vacuum conditions $\left(\sim 10^{-5} \mathrm{mbar}\right)$.

\subsection{Microstructural and Mechanical Characterization}

Different techniques were employed to characterize the porosity at different levels (superficial and volumetric), as well as the pore distribution, shape, and roughness previously reported [3-5,14]. Total porosity was determined by both Archimedes' method and image analysis (IA), using a Nikon Epiphot optical microscope (Japan) coupled with a Jenoptik Progres C3 camera and Image-Pro Plus 6.2 analysis software. Confocal laser and scanning electron microscopy (SEM, JEOL JSM-6490LV, JEOL, Tokyo, Japan) were used to evaluate the roughness. Considering the importance of pores roughness on bacterial adhesion, X-ray micro-computed tomography (M-CT) was also performed due to its capability to provide three-dimensional (3D) surface roughness data, among other parameters. These measurements were performed using a custom made X-ray scanner composed mainly of a micron focused X-ray source L8121-01 (with a W-target) from Hamamatsu, Japan [22]. Scans were performed at $100 \mathrm{kV}$ and $100 \mu \mathrm{A}$, with a spot size of $5 \mu \mathrm{m}$ and were recorded with a flat panel detector C7943 $(120 \times 120 \mathrm{~mm}, 2240 \times 2368$ pixel), also from Hamamatsu. A 3D reconstruction of the specimen was obtained by acquiring a certain number of X-ray projections during sample rotation over $360^{\circ}$, followed by software reconstruction of these projections. This method allowed for the qualitative and quantitative exploration of the interior structure of the porous Ti samples, with a pixel size down to $6.4 \mu \mathrm{m}$ at a 7.8 -fold magnification. Parameters such as equivalent diameter $\left(\mathrm{D}_{\mathrm{eq}}\right)$, total porosity $\left(\mathrm{P}_{\mathrm{t}}\right)$, and interconnected porosity $\left(\mathrm{P}_{\mathrm{i}}\right)$ was determined by M-CT. All these analytical techniques have been implemented, following the procedures described in previous works [3-5,14].

On the other hand, the macro-mechanical behavior of Ti substrates was evaluated by ultrasound technique (dynamic Young's modulus, $\mathrm{E}_{\mathrm{d}}$ ) and uniaxial compression test (Young's modulus, $\mathrm{E}_{\mathrm{c}}$; yield strength, $\sigma_{\mathrm{y}}$ ). For mechanical compression testing, the specimen dimensions were fixed to standard recommendation (height/diameter $=0.8$ ). The tests were carried out with a universal electromechanical Instron machine 5505 by applying a strain rate of $0.005 \mathrm{~mm} / \mathrm{mm} / \mathrm{min}$. All tests finished for a strain of 50 pct. The Young's modulus estimation from the compression stress-strain curves was corrected with the testing machine stiffness $(87.9 \mathrm{kN} / \mathrm{mm})$. On the other hand, conventional microhardness studies (Vickers indenter Shimadzu, model HMV-G, Japan) at two different applied loads (HV0.3 and HV1) were performed. All the measures were taken three times per substrate type and applied load.

\subsection{In Vitro Cellular Experiments}

\subsubsection{Analysis of Bacterial Behavior of Porous Substrates}

E. coli strain Bacterial behavior on porous and fully-dense c.p. Ti substrates is studied, following the protocol summarized in Figure 1. The used E. coli was a lyophilized form from Ielab, Spain (E. coli; ATCC 25922). The culture solution was prepared with Peptone Water (dehydrated culture media, from Panread AppliChem, Spain) and E. coli-Coliforms Chromogenic Medium from Conda Laboratories S.A. The initial concentration of colony-forming units per $100 \mathrm{~mL}$ (CFU/100 mL), was determined by membrane filtration, followed by incubation of the membrane on a Petri plate containing E. coli-Coliforms Chromogenic Medium at $37^{\circ} \mathrm{C}$ for $24 \mathrm{~h}$. Specifically, the study includes three initial concentrations: $7.8 \cdot 10^{4}(\mathrm{C} 1), 3.3 \cdot 10^{3}$ (C2), and $4.3 \cdot 10^{2}$ (C 3) CFU/100 mL, respectively. 


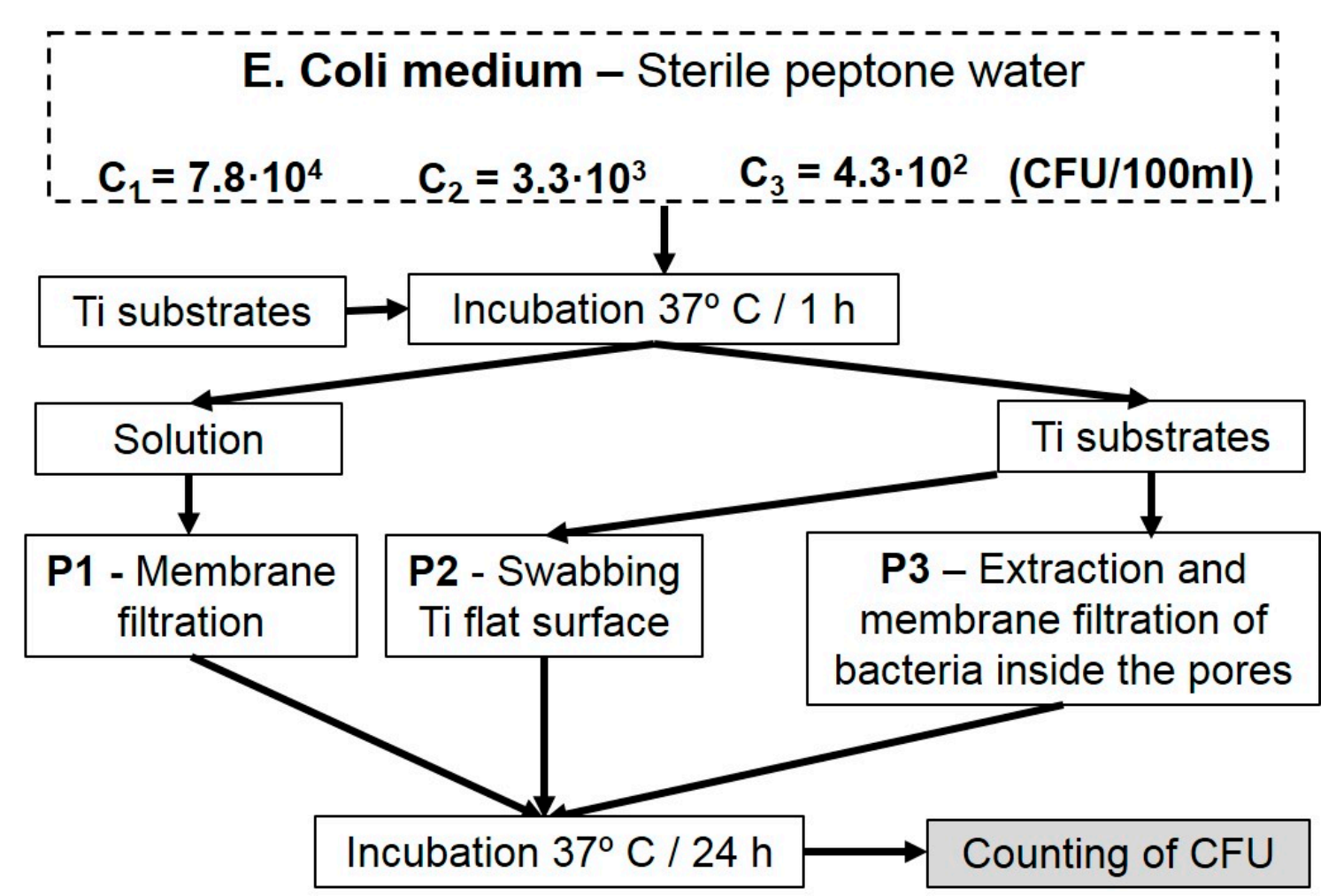

Figure 1. Analytical procedures employed to E. coli bacteria analyses.

For E. coli bacterial behavior studies, fully-dense and porous substrates were placed in $10 \mathrm{~mL}$ test tubes containing each bacterial concentration and these were incubated at $37^{\circ} \mathrm{C}$ for $1 \mathrm{~h}$. One tube containing only bacteria was used as reference (R).

Afterwards, the bacterial growth was analyzed by three protocols (Figure 1). Protocol 1 (P1) quantified the amount of $E$. coli per tube and per initial concentration by membrane filtration (pore size of the membrane: $0.45 \mu \mathrm{m}$ ) of the solution of each tube [23]. Protocol 2 (P2) evaluated the E. coli density on the Ti substrate using a sterile swab to smear the total surface of the Ti samples. P2 was applied on the flat surface, meaning the areas of the samples without pores. Then, the swab was applied following a zigzag pattern on a Petri dish containing E. coli-Coliforms Chromogenic Medium and incubated at $37^{\circ} \mathrm{C}$ for $24 \mathrm{~h}$. Protocol 3 (P3) analyzed the E. coli proliferation inside the pores by re-immersing the swabbed substrates in test tubes with $10 \mathrm{~mL}$ of sterile Peptone water. This solution was mixed using a vortex mixer for $1 \mathrm{~min}$ and cooled at $4{ }^{\circ} \mathrm{C}$ for $2 \mathrm{~h}$. Tube contents were again mixed with the vortex mixer to detach the bacteria from the cavities and to quantify them using membrane filtration. To guarantee the complete detachment of bacteria from the cavities, the process was repeated three times instead of doing it only once as recommended by ISO 11737:1:2007 standard [24]. The bacterial growth was expressed in total number of CFU for each substrate and concentration. Several measurements were made for each condition (protocol, substrate, and initial concentration).

\subsubsection{Evaluation of Cell Adhesion and Proliferation of Eukaryotic Murine C2c12-Gfp Premioblast Cells}

Attachment and proliferation of C2C12-GFP were analyzed by inverted fluorescence microscopy (Olympus IX51) and CellD Software (Olympus). To that end, C2C12 murine premioblastic cell line was purchased to America Type Culture Collection (ATCC ${ }^{\circledR} C R L-1772^{\mathrm{TM}}$ ) and transfected, via lentivirus, to self-express constitutively green fluorescent protein (GFP). The presence of this GFP group in cells membrane allowed us to detect the cells and follow the adhesion and proliferation process. The routing passage was performed using DMEM (Dulbecco's modified Eagle medium, Sigma Aldrich), completed with $10 \%$ fetal bovine serum (FBS) and $1 \%$ of penicillin/streptomycin (100 U/mL, Invitrogen, Germany). For adhesion and proliferation studies, cells were seeded at an initial density of 10,000 cells/ $\mathrm{cm}^{2}$, 
and after $24 \mathrm{~h}$ samples were transferred to new 24-well plates and inverted fluorescent images were taken after day $1,4,7$, and 10 of cell incubation. The complete medium was changed every 2-3 days. This protocol is summarized in Figure 2.

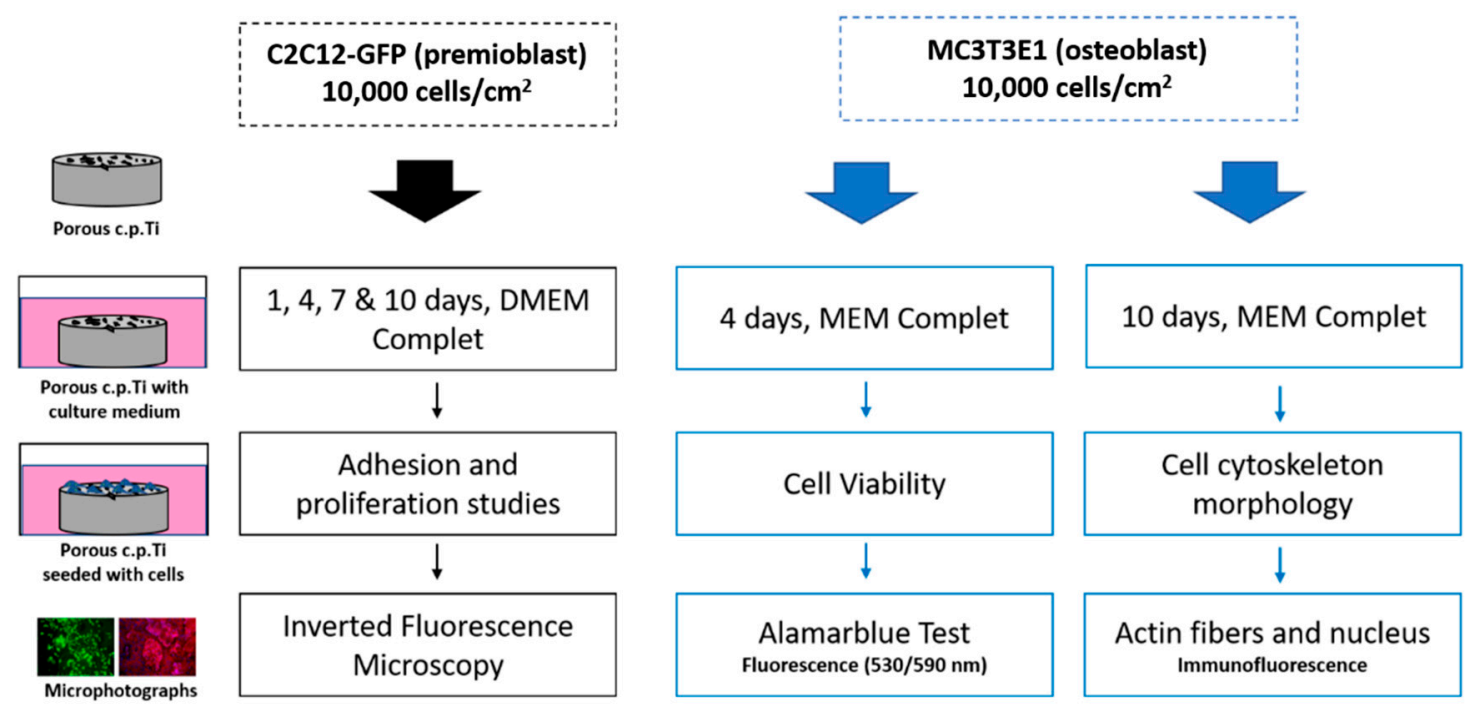

Figure 2. Analytical protocols for the cell studies.

\subsubsection{Cell adhesion and Proliferation Studies of Murine MC3T3E1 Osteoblast}

A bone cell line, MC3T3-E1 (ATCC CRL-2593), was employed to evaluate the effect of porosity in cell viability, cell proliferation, and cell morphology of osteoblast. The subculture routing was performed in MEM (minimum essential medium, Sigma Aldrich, Germany), completed with 10\% fetal bovine serum (FBS) and 1\% of penicillin/streptomycin (100U/mL, Invitrogen, Germany). $75 \mathrm{~cm}^{2}$ culture flasks were placed in a humid atmosphere with $5 \% \mathrm{CO}_{2}$ at $37^{\circ} \mathrm{C}$. Ti substrates were seeded at 10,000 cells $/ \mathrm{cm}^{2}$ and after $24 \mathrm{~h}$ samples were transferred to new 24 -well plates. Figure 2 summaries the protocol for this study.

\section{Cell Viability of Murine MC3T3E1 Osteoblast}

Cell metabolic analysis was measured in order to evaluate the cell viability at day 4 of cell incubation. To that end, AlamarBlue assay (DAL1100, Thermofisher, USA) was performed following the manufacturer's instructions. For this, samples previously seeded with cells were transferred to new 24 -well plates and fresh media containing AlamarBlue dye added ( $10 \%$ of culture media volume). After $1.5 \mathrm{~h}$ of incubation in darkness at $37^{\circ} \mathrm{C}$, samples were removed and fluorescence signal was read in a microplate reader (Synergy HT, Biotek) using an excitation wavelength of $530 \mathrm{~nm}$ and emission wavelength of $590 \mathrm{~nm}$. Fully dense surface was considered control surface as $100 \%$ viability. Assays were carried out by triplicate for each sample condition.

\section{Cellular Morphology Evaluation of Murine MC3T3E1 Osteoblast}

After 10 days of cell incubation, osteoblast cells attached to the substrates were washed twice with PBS, and subsequently, fixed using $4 \%$ paraformaldehyde (PFA) solution. Fully-dense and porous Ti samples were rinsed carefully with PBS twice, permeabilized with $0.1 \%(\mathrm{v} / \mathrm{v})$ Triton X-100 and, finally, washed again with PBS. The actin cytoskeleton was stained with Texas $\operatorname{Red}^{\circledR}{ }^{\circledR} \mathrm{X}$ phalloidin (Molecular Probes). To that end, the commercial solution was prepared in PBS and left in dark conditions for $20 \mathrm{~min}$ at room temperature (RT). Hoechst (Invitrogen, Molecular Probes) was employed as a contrast marker, to detect cell nuclei. Fully-dense and porous substrates were analyzed using an inverted fluorescence microscope (Olympus IX51) with a TRICT filter $(\lambda e x / \lambda e m=550 / 600 \mathrm{~nm})$ for Actin, and DAPI filter for Hoechst $(\lambda \mathrm{ex} / \lambda \mathrm{em}=380 / 455 \mathrm{~nm})$ and images were treated by CellD analysis software (Olympus). 
Statistical Analysis

In general, each experiment was performed in triplicate with each bacteria or cell line, media, and sample. Mean values and standard deviation are reported. A $p$-value of $<0.01$ was deemed to be statistically significant. For in vitro cells, mean and standard deviation are presented and a one-way ANOVA followed by a post Tukey analysis was performed in which values were be statistically significant when $p$-value was $<0.05$.

\section{Results}

\subsection{Microstructural Characterization}

Results concerning to the microstructural characterization of the porous substrates can be observed in Figures 3 and 4. Particularly, Figure 3 (top) shows micro-images of the fabricated samples while Figure 3 (bottom) displays details about the aspect of the pores, size, and distribution as obtained by IA. So, by the micro-image we have an overview of the fabricated samples, while by IA details about the aspect of the pores, size and distribution can be determined. Figure 4 shows data obtained by $\mathrm{M}-\mathrm{CT}$ which provides three-dimensional information, quite useful to determine the distribution of inner pores as well as the roughness volume percentage of the eroded pore compared to the virtually smoothed pore in dependence of the pore equivalent diameter. The presence of micro-scale roughness pattern within the pores was revealed by M-CT, so total inner surface was calculated analyzing a M-CT representative fraction of total sample volume, taking into account the local deviation of the gray values perpendicular to the contour line within a search distance of $20 \mu \mathrm{m}$. Data obtained by the analyses of the images contained in Figures 3 and 4 are summarized in Tables 1 and 2, such as porosity and parameters to characterize the pores (equivalent diameter of pores, $\mathrm{D}_{\text {eq, }}$ shape factor, and roughness).

Table 1. Total, interconnected, and isolated porosity evaluated by different characterization techniques.

\begin{tabular}{ccccccc}
\hline \multirow{2}{*}{ Samples } & \multicolumn{3}{c}{$\boldsymbol{P}_{\boldsymbol{T}} \mathbf{( \% )}$} & \multicolumn{2}{c}{$\boldsymbol{P}_{\boldsymbol{i}}(\mathbf{\%})$} \\
\cline { 2 - 7 } & $\begin{array}{c}\text { Archimedes' } \\
\text { Method }\end{array}$ & IA & M-CT & $\begin{array}{c}\text { Archimedes' } \\
\text { Method }\end{array}$ & M-CT \\
\hline \multicolumn{2}{c}{ Fully-dense } & $2.3 \pm 0.1$ & $1.2 \pm 0.2$ & - & $2.1 \pm 0.1$ & - \\
\hline \multirow{2}{*}{$\begin{array}{c}\text { Spacer size } \\
(\mu \mathrm{m})\end{array}$} & $100-200$ & $44.8 \pm 0.1$ & $50.3 \pm 1.3$ & $52.2 \pm 10.7$ & $43.1 \pm 0.2$ & $51.3 \pm 10.6$ \\
\cline { 2 - 7 } & $250-355$ & $45.9 \pm 0.2$ & $48.7 \pm 1.9$ & - & $41.0 \pm 0.1$ & - \\
\hline
\end{tabular}

Table 2. Morphological features of the pores: size, shape factor, and roughness of the pore walls.

\begin{tabular}{|c|c|c|c|c|c|}
\hline \multirow{2}{*}{\multicolumn{2}{|c|}{ Samples }} & \multicolumn{2}{|c|}{ AI } & \multicolumn{2}{|c|}{ M-CT } \\
\hline & & $D_{e q}(\mu \mathrm{m})$ & Shape factor & $D_{e q}(\mu \mathrm{m})$ & Roughness, $R_{a}(\%)$ \\
\hline \multicolumn{2}{|c|}{ Fully-dense } & $5.5 \pm 0.2$ & $0.99 \pm 0.01$ & & - \\
\hline \multirow{3}{*}{$\begin{array}{l}\text { Spacer size } \\
\quad(\mu \mathrm{m})\end{array}$} & $100-200$ & $161.1 \pm 28.5$ & $0.67 \pm 0.03$ & $191.8 \pm 6.1$ & $11.3 \pm 2.5$ \\
\hline & $250-355$ & $261.5 \pm 9.0$ & $0.67 \pm 0.01$ & $311.9 \pm 8.2$ & $7.3 \pm 2.0$ \\
\hline & $355-500$ & $293.4 \pm 28.2$ & $0.71 \pm 0.03$ & $368.4 \pm 9.1$ & $3.3 \pm 0.6$ \\
\hline
\end{tabular}




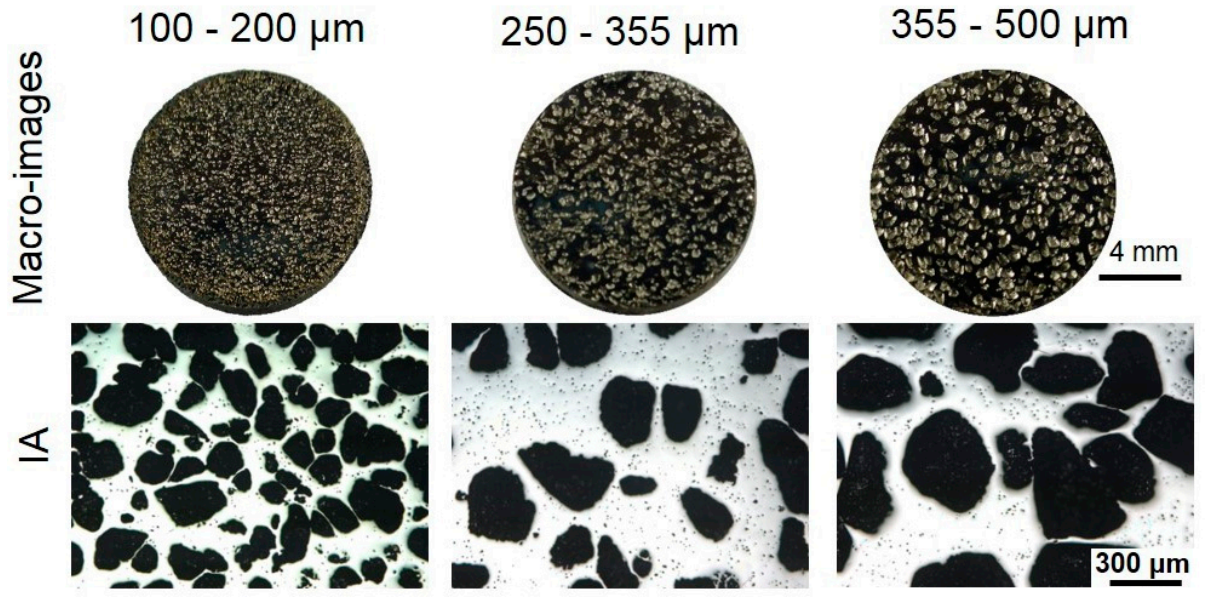

Figure 3. Macro-photography of the samples and optical microscopy images of the porous substrates for the different ranges of spacer particles size: 100-200 $\mu \mathrm{m}, 250-355 \mu \mathrm{m}$, and 355-500 $\mu \mathrm{m}$.
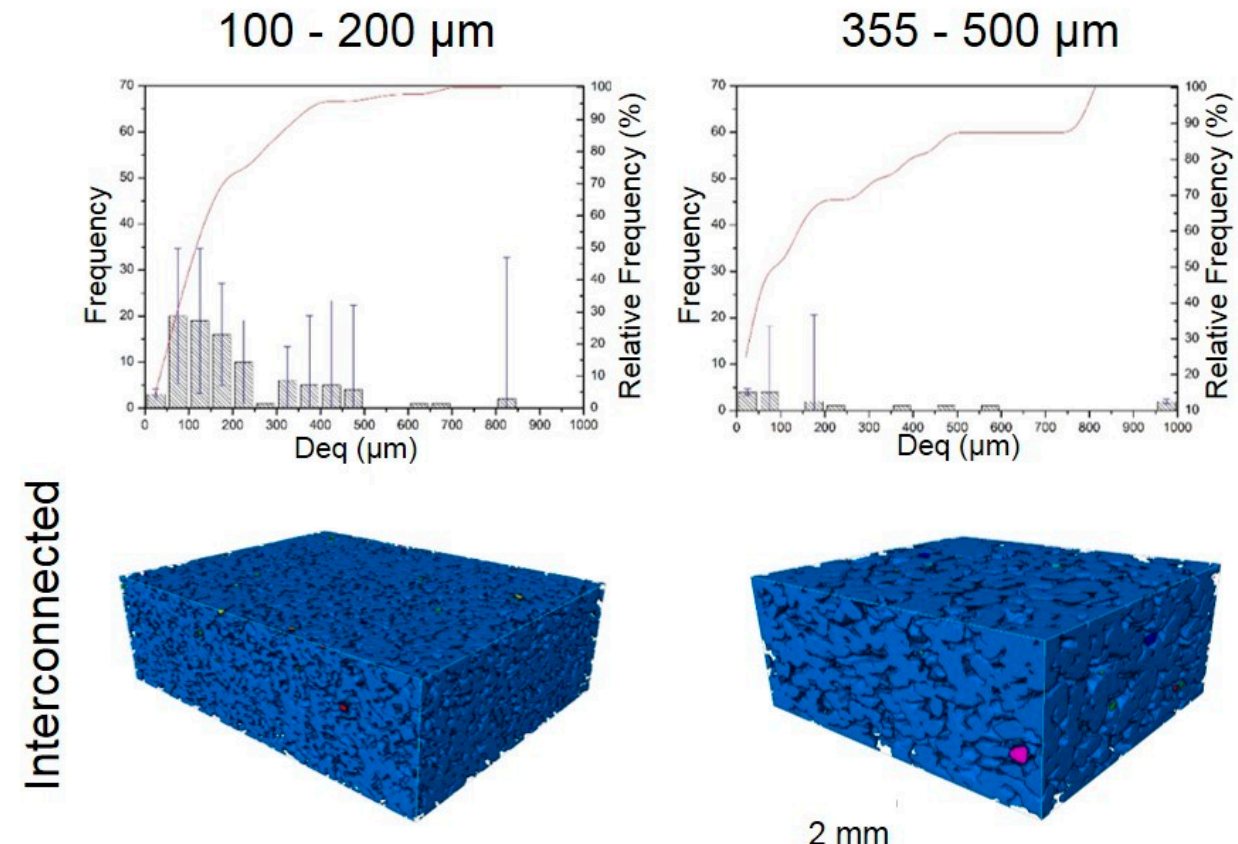

$\underline{2 \mathrm{~mm}}$
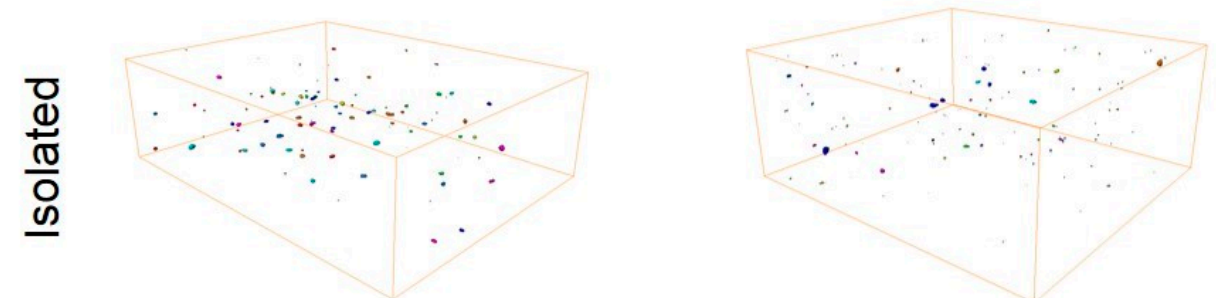

Figure 4. Equivalent diameter determined and interconnected and isolated porosity analyzed by M-CT for two different ranges of spacer particles size: 100-200 $\mu \mathrm{m}$ and 355-500 $\mu \mathrm{m}$.

\subsection{Mechanical Behavior}

The macro-mechanical (stiffness, yield strength) and micro-mechanical (Vickers hardness) behavior of porous c.p. Ti is summarized in Table 3. Young's modulus has been measured by ultrasound and uniaxial compression test. These results have been discussed in terms of the advantages and 
disadvantages of both techniques. On the other hand, the influence of the indentation load and its relationship with the size of the remaining Ti matrix among pores is evaluated. In this context, it should be noted that, for a fixed percentage of total porosity, an increase in pore size implies an increase in the mean distance between pores (the size of the titanium matrix increases).

Table 3. Macro and micro-mechanical behavior of porous substrates.

\begin{tabular}{ccccccc}
\hline \multirow{2}{*}{ Samples } & \multicolumn{2}{c}{ US } & \multicolumn{2}{c}{ Uniaxial Compression Test } & \multicolumn{2}{c}{ Microhardness } \\
\cline { 2 - 7 } & $\boldsymbol{E}_{\boldsymbol{d}}(\mathbf{G P a})$ & $\boldsymbol{E}_{\boldsymbol{c}}(\mathbf{G P a})$ & $\left.\sigma_{\boldsymbol{y}} \mathbf{( M P a}\right)$ & $\boldsymbol{H V 0 . 3}$ & $\boldsymbol{H V 1}$ \\
\hline \multicolumn{2}{c}{ Fully-dense } & $101.2 \pm 0.3$ & $95 \pm 1.0$ & $628 \pm 5$ & $377 \pm 26$ & $342 \pm 52$ \\
\hline \multirow{3}{*}{$\begin{array}{c}\text { Spacer size } \\
(\mu \mathrm{m})\end{array}$} & $100-200$ & $20.8 \pm 0.1$ & $26.0 \pm 0.9$ & $127 \pm 21$ & $401 \pm 42$ & $167 \pm 81$ \\
\cline { 2 - 7 } & $250-355$ & $22.8 \pm 0.2$ & $23.1 \pm 1.0$ & $118 \pm 14$ & $356 \pm 35$ & $152 \pm 72$ \\
\cline { 2 - 7 } & $355-500$ & $20.0 \pm 0.7$ & $19.7 \pm 1.2$ & $98 \pm 18$ & $350 \pm 36$ & $138 \pm 70$ \\
\hline
\end{tabular}

\subsection{Bacteria Behavior}

The number of CFU of E. coli on titanium substrates as a function of initial bacteria concentration following Protocol 1 is depicted in Figure 5a. It was observed that E. coli initial concentration affected the number of $\mathrm{CFU}$ on the substrate i.e., the higher the initial concentration the higher the number of CFU. However, as porosity increased (fully-dense vs. porous c.p. Ti) the number of CFU was significantly increased, especially at the lowest initial bacteria concentration (C3). E. coli bacteria concentration of the medium could influence the medium-substrate interaction. After incubating the samples for $1 \mathrm{~h}$ at $37^{\circ} \mathrm{C}$, the number of $\mathrm{CFU}$ in the corresponding solutions was determined by membrane filtration. Protocol 2 revealed no bacteria attached onto the flat surface. By Protocol 3 , bacteria inside the pores was quantified and its normalization by the surface is shown in Figure $5 b, c$, respectively. As the size of the spacer increased the number of CFU also increased at both initial bacteria concentrations (Figure 5b).
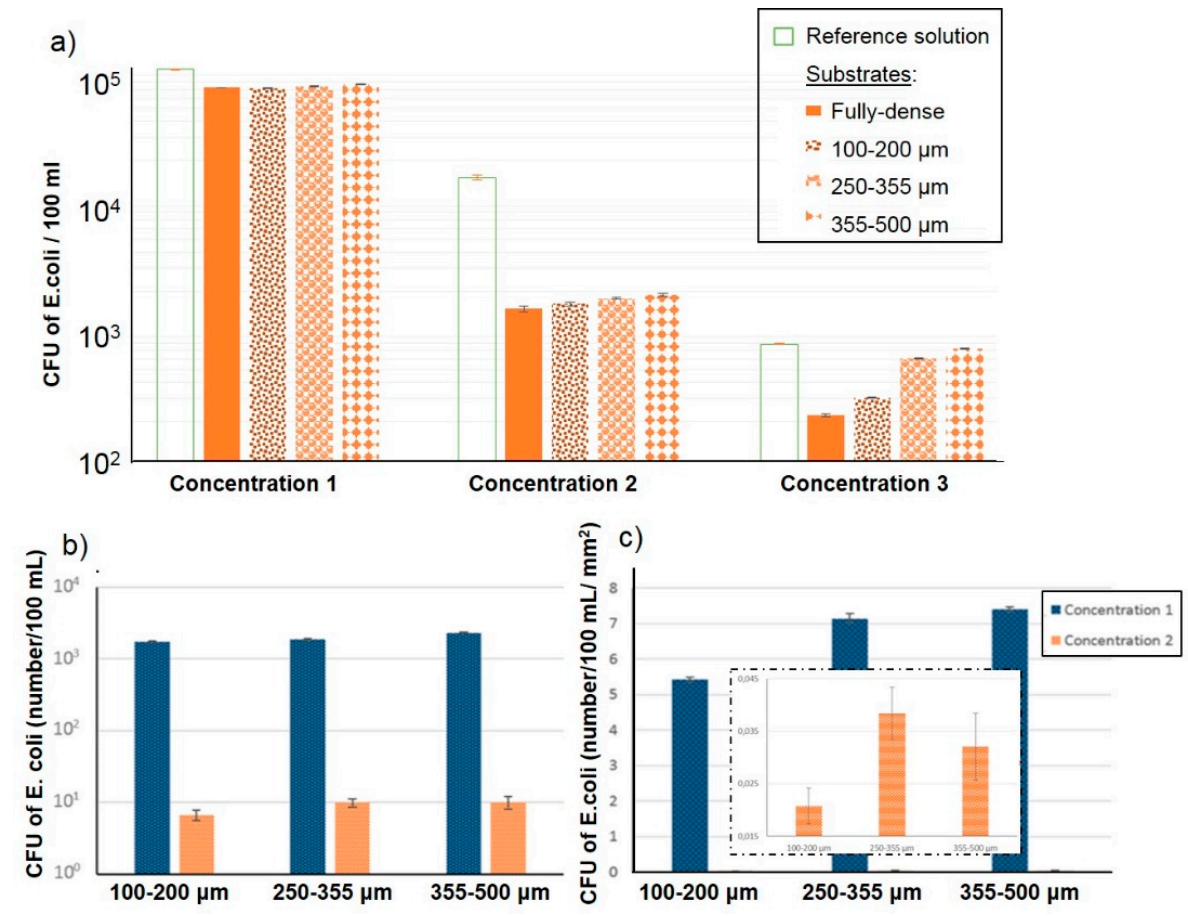

Figure 5. Bacteria quantification following protocols described (P1, P2, and P3). (a) CFU of E. coli bacteria after membrane filtration (Protocol 1), CFU of E. coli bacteria inside the pores measured following Protocol 3: (b) absolute values and (c) normalized values by the inner pores surface. Inset: magnification view of the concentration view for the normalized values. 


\subsection{In Vitro Cell Studies}

The different studied substrates were tested in vitro conditions using two murine cell lines. In first place, C2C12-GFP premioblastic line was used to evaluate the process of cell adhesion and proliferation after 1, 4, 7, and 10 days of cell culture compiling the results in Figure 6. C2C12-GFP cells were capable to attach and proliferate over the surface and inside the pores, increasing the cell density presented on the samples over time. In the first $24 \mathrm{~h}$, the inverted fluorescence images showed similar cell density between fully-dense and porous substrates. After 4 days, several small green dots which correspond to small alive cell clusters were observed totally dispersed on the surface. Furthermore, at longer incubation periods, cells were able to proliferate, showing an increased cell density over the entire surface. Indeed, at day 10 C2C12 GFP cells were covering the entire porous structure, even filling the pores attaching on pore's walls and arriving to the edge of the samples (see Figure 7 after 10 days, 255-350 $\mu \mathrm{m}$ sample). Figure 7 showed a higher magnification of C2C12-GFP cells growing at 4 days to analyze the cell morphology on c.p. Ti samples. A clear different cell shape was observed between cells growing on flat surfaces and inside pores. Premioblastic cells growing on fully-dense samples showed fusiform morphology, with an elongated cell shape. This cell morphology, most frequent of fibroblastic phenotype, was also observed in flat surfaces of porous substrates independently of pore size (see Figure 7).
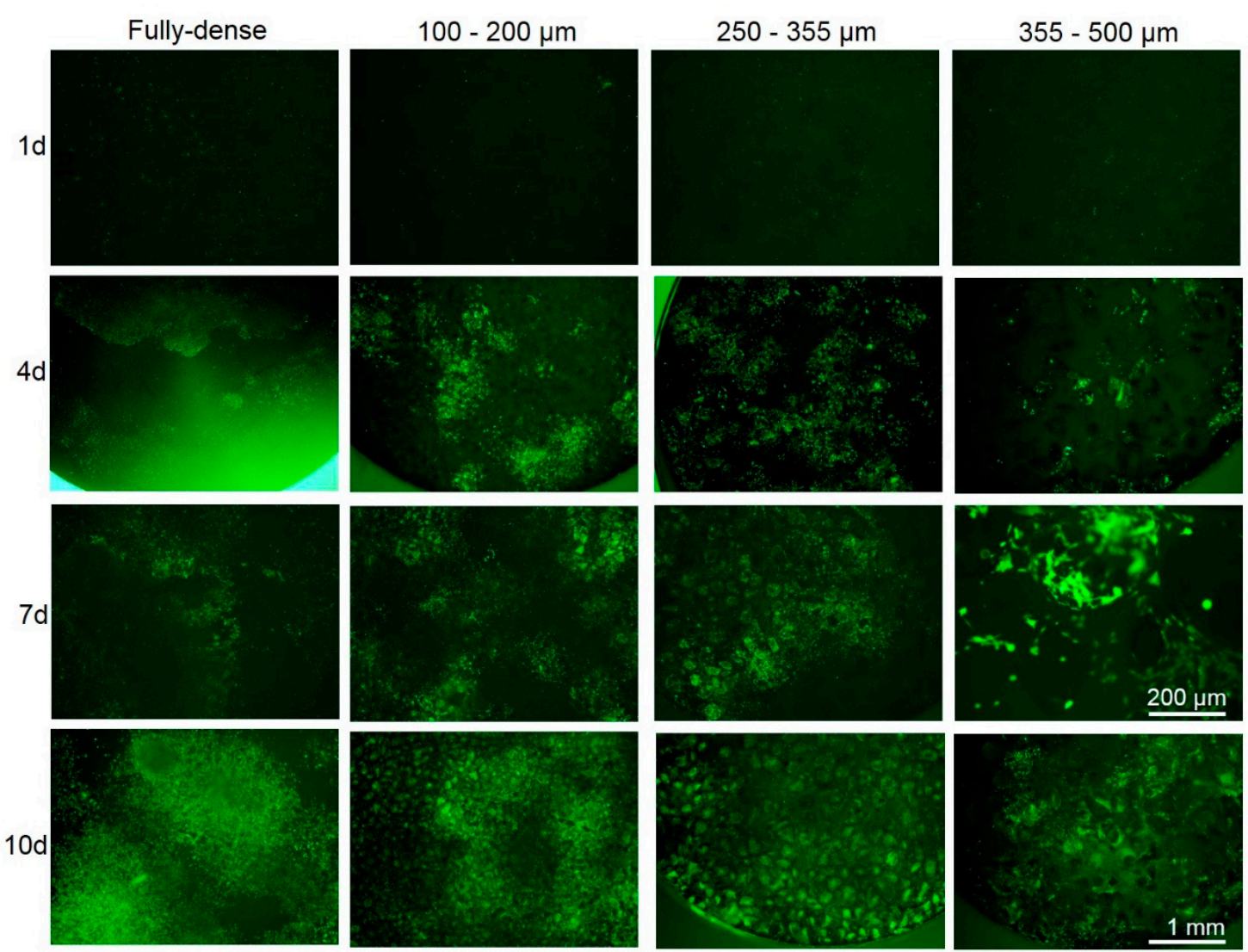

Figure 6. Inverted fluorescence microphotographs of cell adhesion and proliferation of C2C12-GFP cells after 1, 4, 7, and 10 days of cell culture. Common scale bar, $1 \mathrm{~mm}$, except for 7 days and pore size $355-500 \mu \mathrm{m}$, which a specific scale bar is indicated $(200 \mu \mathrm{m})$. 

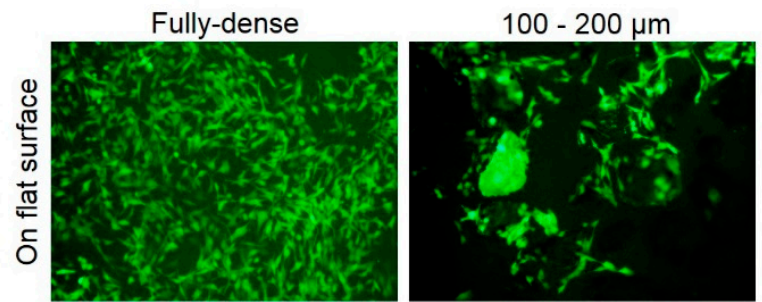

$250-355 \mu \mathrm{m}$
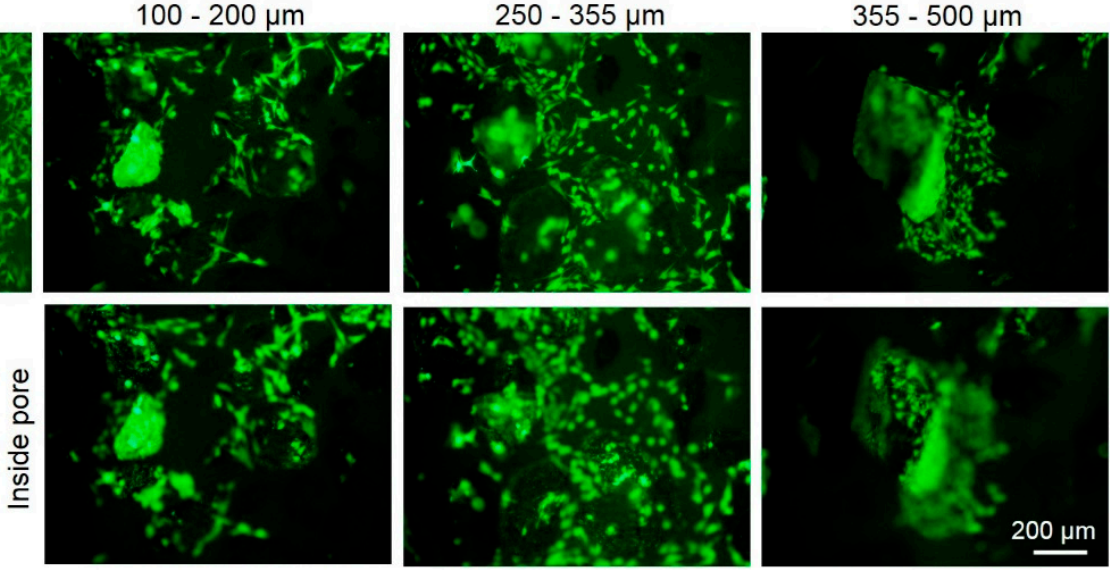

Figure 7. Higher magnification of microphotographs of C2C12-GFP cells growing after day 4 of cell incubation. Common scale bar.

Cell viability determination was performed after 4 days using osteoblast cells and the results were compiled in Figure 8. Cell viability was expressed as percentage of fully dense samples, showing an increased cell viability of osteoblast growing on the three porous structures compared to the control surface (fully-dense). Although cell viability results are slightly higher for porous samples respect to fully-dense substrates, this observed trend was not statistically significant and, therefore, no differences in cell viability could be observed between surfaces $(p>0.05)$.

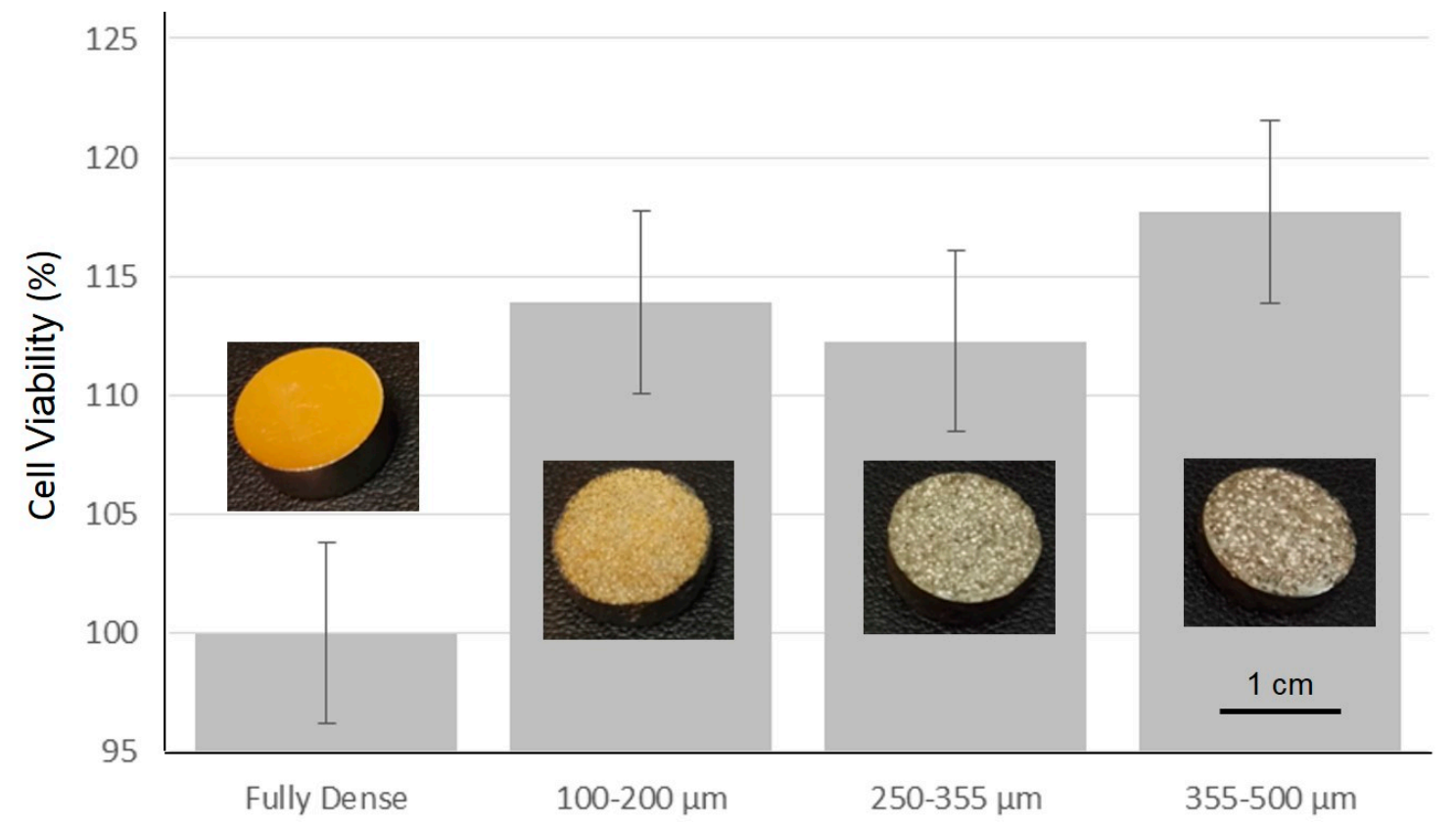

Figure 8. Cell viability quantification of preosteoblast MC3T3 growing on fully-dense and porous substrates after 4 days of cell incubation. Percentages of cell viability are coupled with representative images from a macroscopic point of view. No statistics differences were observed between surfaces $(p>0.05)$, however, porous substrates reached higher percentages than the control fully-dense surface. Common scale bar for all the images.

Figure 9 presents the images of preosteoblast MC3T3E1 cell cytoskeleton morphology, showing actin fibers (in red) and cell nuclei of stained osteoblast (in blue) after 10 days of cell culture. Firstly, it was observed that, the entire surface of fully-dense and porous substrates was completely covered by osteoblast. Some flat areas in samples prepared with higher space-holder particles size $(355-500 \mu \mathrm{m})$ 
were not totally covered and a heterogeneous random distribution was observed compared to the homogeneous cell spread of osteoblast in the other three surfaces. Images on the middle and bottom depict porous structures in Figure 9 corresponds to a higher magnification area (using 10× and 20× lenses). These micro-photographs showed the same area with focusing in two different points, on flat surface and inside pores. As it is shown, the cell nuclei of MC3T3E1 cells in the three porous substrates were covering the total flat surface exposed and the elongated actin fibers connecting between cells almost producing a cell sheet. In contrast, fully-dense surfaces revealed more than one cell monolayer growing on top of another cell sheet. This situation might reduce the corresponding cell viability of the cell culture and promote the detachment of the cell sheet.

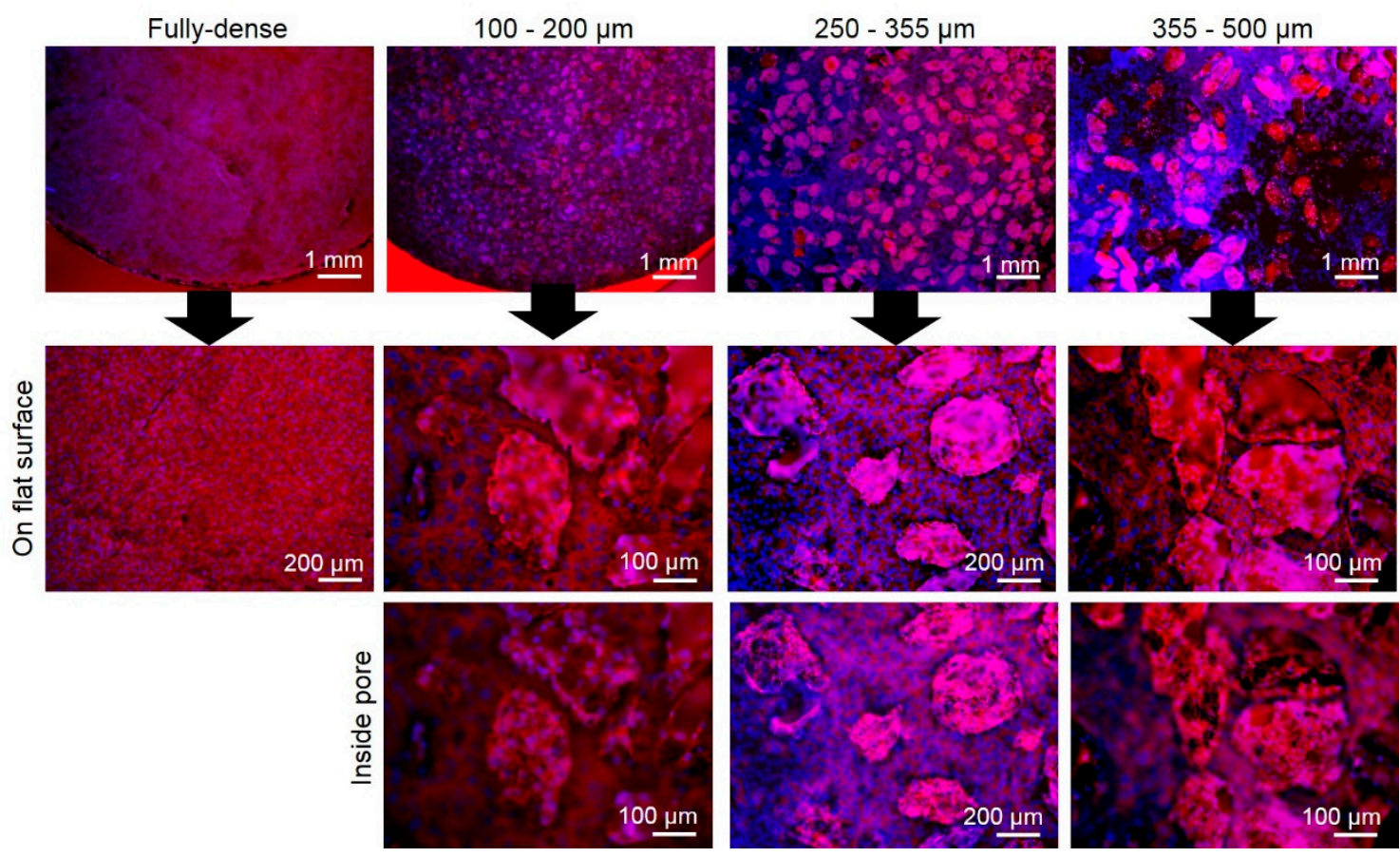

Figure 9. Immunofluorescence images of cell actin cytoskeleton (in red) and cell nuclei (in blue) of preosteoblast MC3T3 growing for 10 days. Medium and lower images correspond to higher magnification of areas focusing in same area on flat and inside pores of the studied specimens. Bottom images show the cells attached inside pores and medium the same cells well focused on flat areas.

\section{Discussion}

As it is shown in the optical microscopy images (Figure 3), all porous c.p. Ti substrates present two different ranges of pore sizes; pores with a size below $50 \mu \mathrm{m}$ were generated during the sintering process. In addition, they are not critical in mechanical and biological behavior of the substrates. Otherwise, the larger pores correspond to the former spacer particles, showing a $D_{e q}$ in the range of the size of these particles $(161.1 \pm 28.5 \mu \mathrm{m}$ for $100-200,261.5 \pm 9.0 \mu \mathrm{m}$ for $250-355$, and $293.4 \pm 28.2 \mu \mathrm{m}$ for the 355-500 $\mu \mathrm{m}$ of the spacer particles size, as it was determined by IA). Porosity results obtained by the different techniques (Table 1) differ due to the inherent characteristics of them: Archimedes' is a volumetric method, IA analysis is superficial while M-CT only takes into account a volumetric fraction of the sample. The total porosity is slightly below the expected $50 \%$. Nevertheless, different factors can influence. For instance, remaining small amount of undissolved $\mathrm{NH}_{4} \mathrm{HCO}_{3}$, which are enclosed in the isolated pores, and the slight reduction of the volume associated with the space-holder during sintering would contribute to reduce the porosity while an increase on the porosity could be also expected because of the additional micro-pores generated during the sintering. 
Total inner surface has been calculated analyzing a M-CT representative fraction of total sample volume. The lowest value was obtained for the intermediate size 255-350 $\mu \mathrm{m}\left(260.1 \pm 29.6 \mathrm{~mm}^{2}\right)$, while similar values were calculated for the other samples (321.0 \pm 44.8 and 311.9 \pm 29.9 for 100-200 $\mu \mathrm{m}$ and $350-500 \mu \mathrm{m}$, respectively). Similarly, roughness quantification by the analysis of confocal microscopy images revealed an increased roughness in porous surfaces compared to flat surface, as it has been described above.

Concerning the pores, $D_{e q}$, analyzed by IA and M-CT (see Table 2), a similar tendency was observed for both techniques. In the case of IA, also information about the shape factor has been obtained, revealing high symmetry of the pores, since it is close to one for all the substrates. By M-CT, the roughness has been analyzed (Table 2), the higher pore size $(355-500 \mu \mathrm{m})$, the smoother surface. Roughness improves cellular adhesion [3,5], so it is desirable for osseointegration; however, depending on the roughness values it can affect bacteria adhesion.

Additionally, the mechanical behavior of the substrate is an important feature since the ideal implant should be mechanically similar to the bone. The mechanical properties of the fully-dense substrates are far from those of cortical bone tissues. However, all porous substrates present a Young's modulus similar to the one of the cortical bone [25]. The yield strength values of the porous samples are lower than that of the bone, but they remain closer to the ideal values compared with fully-dense substrates [26].

Microhardness has been evaluated by two load levels that reveal different results: HV0.3 and HV1 (Table 3). Comparing the results, the differences in terms of applied load for one substrate could be related to the localized microplasticity phenomena and indentation size effects. The microhardness and the local stiffness of the porous c.p. Ti substrates depend on the remaining material and the surrounding pores (size and distribution). For low load (HV0.3), the microhardness of porous substrates and fully-dense samples is similar due to the Ti matrix remaining sufficiently large between the pores (i.e., no porosity influence). However, for higher load (HV1), an effect of the pore and porosity on the micro-mechanical behavior (material collapse, buckling, etc.) can be appreciated. The pore size influences the microhardness in an opposite way, it means, the samples with a higher pore size present a lower microhardness value due to the larger area of the Ti-matrix among the pores. However, a detailed study may be required to determine the main influential parameters to the results as the mean free path between pores and the number of indentations.

Once the mechanical properties have evaluated, next the bio-functional behavior is studied. Following Protocol 1, the bacteria concentration of the medium was measured. As it is shown in Figure $5 \mathrm{a}$, both fully-dense and porous substrates inhibited the bacterial growth for the three studied concentrations compared to the reference solution (bacteria only). This reduction was particularly significant for fully-dense c.p. Ti substrates and lower initial bacteria concentrations (C3) while for bacteria solution (C1), the substrate influence was irrelevant. This difference between the fully-dense and the porous samples can be explained by two possible factors: the growth rate is higher for lower bacteria concentrations in the media, achieving a stationary state and/or higher concentrations of bacteria mean that the bacteria thronged the cavities, hampering penetration into the pore.

Measurements obtained by Protocol 2 for the E. coli strain showed no bacteria growth and adhesion onto the flat surfaces. For the porous samples, the flat surface corresponds to the polished c.p. Ti matrix surface that remains among all the pores. After incubating the Petri dish where the swab was smeared, no bacteria grew. For this same strain, Protocol 3 revealed bacterial presence inside the pores (Figure 5). This difference in terms of behavior between the two surfaces could be related to the micro-roughness pattern of the porous surface. A similar pattern has been reported for osteoblasts [4,5]. As it is shown in Figure 5b, the number of CFU inside the pores was larger for porous substrates with larger pore size and at higher concentrations. A higher initial bacteria concentration implies higher probability of bacteria attaching inside the pores. The influence of the pore size could be ignored compared to the effect of the concentration for absolute values. Nevertheless, once the number of CFU was adjusted in relation to the area (Figure 5c), it was relatively insignificant. 
To compare the bacteria behavior and the studied substrates different factors have been considered. On the one hand, the presence of pores and, on the other hand, the real surface, which is related to pores inner roughness. In this context, it has been observed that the presence of pores promote bacteria proliferation. Otherwise, normalized values by real surface area reveals that the value was not higher than expected. Pore number, size, shape, and surface roughness inside the pores are also relevant. At higher pore size $(368.4 \pm 9.1 \mu \mathrm{m})$ as measured by $\mathrm{M}-\mathrm{CT}$, more bacteria are adhered into them. In contrast, bigger pores present smoother walls $(3.3 \pm 0.6 \mu \mathrm{m})$, which would make more difficult the bacteria adhesion. However, the obtained results for this bacteria strain show that pore size is more significant than roughness.

Regarding the behavior of mammalian cells such as myoblast or osteoblast cell lines, several studies have been performed. Cell viability, adhesion, proliferation, and differentiation of osteoblast are key factors for bone tissue reconstruction purposes [27] and these processes can be influenced by tailoring the surface properties of the medical device such as hydrophilicity, roughness, pore size, morphology, and distribution. Pore size is one key parameter that has been deeply reported in several studies suggesting pore size between $20 \mu \mathrm{m}$ to $500 \mu \mathrm{m}$ are appropriate for bone regeneration [28]. These values covered a wide range of pore sizes, however, if the pores are quite small, the blood vessel network cannot exchange nutrients and oxygen to new bone tissue. Conversely, if the pore is too large, the mechanical properties may compromise the internal stability of the implant. Although the most suitable pore size for bone regeneration process is still controversial, for Ti implants a pore range from 150 to $500 \mu \mathrm{m}$ has been established, taking into account the role of the interconnected pores in the proper development of the new vascularization system [29]. During the course of this study, all porous surfaces showed a non-toxic behavior and a good cell adhesion for C2C12GFP achieving similar cell density after $24 \mathrm{~h}$ compared to the fully-dense control surface (Figure 6). In fact, the presence of cells attached on the surface on all c.p. Ti substrates serves as an indicative factor of biocompatibility of the manufacturing process of porous structures by powder metallurgy and space-holder techniques which have been previously described as safety technologies to develop non-toxic 3D porous structures [30].

Even though the cell density attached on the surface after day 1 is low, C2C12GFP cells could proliferate and grew further after 4, 7, and 10 days, increasing the cell density, which was observed as a higher fluorescence intensity signal (Figure 6). After 4 days, C2C12-GFP density increased compared to day 1 . However, premioblastic cells grew in clusters randomly dispersed, leaving flat areas empty without cells attached on the surface. This behavior evolved, and after day 7 , a continuous cell monolayer was developed covering the center and, in some cases, reaching the edges of the c.p. Ti samples, and thus, reducing the flat areas with no cells attached. Some pores were covered by osteoblast after 10 days which appeared as intense green fluorescence signal. Here, many areas were totally covered, including flat and inside pores, in which cells were expanded and connected forming a cell monolayer. At this time, the presence of pores offers a different surface (increased roughness values and surface contact area) which may allow the proper growth of both myofibroblast/osteoblast and E. coli as we have previously described. In case of fully-dense surfaces, the presence of more than one cell monolayer could reduce the cell viability, but bacteria may take advantage and spread and migrate to new sites over the medical implant.

Several authors have reported that the presence of pores (and their size, morphology, roughness, and interconnectivity), the surface chemistry, and surface free energy of metallic based biomaterials have a strong influence on the initial adhesion and early differentiation of osteoblast lineage cells [31-33]. Although the aim of this study was to evaluate the bacteria behavior on porous c.p. Ti structure compared to cell adhesion and proliferation of in vitro cell lines, both C2C12GFP and MC3T3 cells shared some similar points. Firstly, both cell lines were able to attach and proliferate confirming the cell viability values of osteoblast which were higher on porous surfaces over the samples after 4 days (see Figure 8). Even where there were not statistically differences on cell viability, the three porous c.p. Ti substrates achieved higher percentages than control fully-dense surface $(113.89 \%, 112.28 \%, 117.74 \%$, and $100 \%$, respectively). The larger pore size, $355-500 \mu \mathrm{m}$, offered higher cell viability percentage 
which was also correlated to the higher attached E. coli, confirming the higher pore surfaces structure as an advance surface to promote cellular and bacteria adhesion.

Secondly, the specific tailored microstructure of porous scaffolds by space-holder have a strong impact on cell adhesion which one can observe in the differential cell morphology showed in Figures 7 and 9. The cell morphology of osteoblasts is usually a response to the surface properties of the inner material. Inside the pores, osteoblast cells showed a more cuboidal cell cytoskeleton compared to a more fusiform cell shape on flat surfaces (either fully-dense or flat surface of porous c.p. Ti samples). This distinction in cell morphology can be correlated to an advanced cell adhesion state which also can affect other cellular processes such as osteoblast cell differentiation growing inside pores as it was described in the literature [33].

Some reports have described the influence of surface properties on cell morphology and how the shape of the cells is also connected with other cellular functions such as cell adhesion, proliferation, differentiation, and mineralization processes [34,35]. Furthermore, the increased inner roughness values of pores compared to flat surface (of fully-dense or even flat surface of porous samples) has been described as a key factor for osteoblast adhesion and differentiation studied [5,33]. Inside the pores, osteoblast cells attached on the wall perceive higher load transfer and this local stress will promote cell differentiation and mineralization, and therefore, the need for bone ingrowth [33]. However, these cells growing inside pores presented a different cell morphology, revealing a more cuboidal structure, round shape, and less elongation.

The cell morphology observed inside the pores could be related to an advance cell adhesion, being the $100-200 \mu \mathrm{m}$ porous substrate the best pore size to promote cellular adhesion and reduced bacteria attachment compared to larger pore size $355-500 \mu \mathrm{m}$ and fully-dense substrates.

\section{Conclusions}

The microstructural parameters of titanium porous samples fabricated by space-holder technique are consistent with the initial design criteria (characteristics of the spacer holder particles: volume fraction and size range), supporting the viability and reliability of this economic route of manufacturing substrates with controlled porosity. The porous substrates obtained with this technique, in the range of 100-200 $\mu \mathrm{m}$, presented the best mechanical balance (higher Young's modulus, yield strength, and microhardness). Besides, this substrate also revealed the highest interconnected porosity, potentially improving the bone in-growth. It is worth to highlight that both, spacer particle size and pores inner surface topography, have a strong influence on adhesion of osteoblasts and bacteria proliferation (E. coli strain). However, the results revealed that the predominant parameter in bacteria behavior is pore morphology (equivalent diameter). Therefore, the bigger pore size showed higher bacteria attachment. To summarize, substrates with smaller pore sizes can be considered the most suitable, since this range of pore sizes can assure the best biomechanical, cellular, and antibacterial behavior.

Author Contributions: Conceptualization, project administration, supervision J.A.R.-O. and Y.T; Investigation, formal analysis, validation A.C., A.M.B., C.D.-T., M.D.G, J.L., F.G.M., J.V.C.-R., and J.J.G.; Discussion and writing-original draft preparation, all authors.

Funding: This research was funded by the Ministry of Economy and Competitiveness of Spain under the grant MAT2015-71284-P and of the Junta de Andalucía-FEDER (Spain) through the project ref. P12-TEP-1401.

Acknowledgments: The authors dedicate this paper to the memory of Juan J. Pavón Palacio (University of Antioquia, Colombia). Authors thank to A. S., C. L., and M.V.S. for experimental work for bacteria studies. The authors would like to thank J. Pinto for assistance in micro-mechanical testing. AMB also thanks the financial support of the University of Seville for the research stay at Institute of Applied Materials, Helmholtz-Zentrum Berlin für Materialien und Energie, Berlin (Germany) (Grant: VI Plan Propio de Investigación y Transferencia-US 2018, I.3A2).

Conflicts of Interest: The authors declare no conflict of interest. 


\section{References}

1. Kunčická, N.; Kocich, R.; Lowe, T.C. Advances in metals and alloys for joint replacement. Prog. Mater. Sci. 2017, 88, 232-280. [CrossRef]

2. Niinomi, M. Mechanical biocompatibilities of titanium alloys for biomedical applications. J. Mech. Behav. Biomed. Mater. 2008, 1, 30-42. [CrossRef] [PubMed]

3. Torres, Y.; Pavón, J.J.; Rodríguez-Ortiz, J.A. Processing and characterization of porous titanium for implants by using $\mathrm{NaCl}$ as space holder. J. Mater. Process. Technol. 2012, 212, 1061-1069. [CrossRef]

4. Torres, Y.; Pavón, J.J.; Nieto, I.; Rodríguez-Ortiz, J.A. Conventional powder metallurgy process and characterization of porous titanium for biomedical applications. Metall. Mater. Trans. B Process Metall. Mater. Process. Sci. 2011, 42, 891-900. [CrossRef]

5. Muñoz, S.; Pavón, J.J.; Rodríguez-Ortiz, J.A.; Civantos, A.; Allain, J.P.; Torres, Y. On the influence of space holder in the development of porous titanium implants: Mechanical, computational and biological evaluation. Mater. Charact. 2015, 108, 68-78. [CrossRef]

6. Jurczyk, M.U.; Jurczyk, K.; Miklaszewski, A.; Jurczyk, M. Nanostructured titanium-45S5 Bioglass scaffold composites for medical applications. Mater. Des. 2011, 32, 4882-4889. [CrossRef]

7. Trueba, P. Desarrollo de Titanio con Porosidad Gradiente Radial y Longitudinal para Aplicaciones Biomédicas. Ph.D. Thesis, University of Seville, Seville, Spain, 2017.

8. Naebe, M.; Shirvanimoghaddam, K. Functionally graded materials: A review of fabrication and properties. Appl. Mater. Today 2016, 5, 223-245. [CrossRef]

9. Sola, A.; Belluci, D.; Cannillo, V. Functionally graded materials for orthopedic applications—An update on design and manufacturing. Biotechnol. Adv. 2016, 34, 504-531. [CrossRef] [PubMed]

10. Singh, S.; Ramakrishna, S.; Singh, R. Material issues in additive manufacturing: A review. J. Manuf. Process. 2017, 25, 185-200. [CrossRef]

11. Jha, N.; Mondal, D.P.; Majumdar, J.D.; Badkul, A.; Jha, A.K.; Khare, A.K. Highly porous open cell Ti-foam using $\mathrm{NaCl}$ as temporary space holder through powder metallurgy route. Mater. Des. 2013, 47, 810-819. [CrossRef]

12. Torres, Y.; Pavón, J.J.; Trueba, P.; Cobos, J.; Rodriguez-Ortiz, J.A. Design, fabrication and characterization of titanium with graded porosity by using space-holder technique. Procedia Mater. Sci. 2014, 4, 115-119. [CrossRef]

13. Jakubowicz, J.; Adamek, G.; Dewidar, M. Titanium foam made with saccharose as a space holder. J. Porous Mater. 2013, 20, 1137-1141. [CrossRef]

14. Dominguez-Trujillo, C.; Ternero, F.; Rodriguez-Ortiz, J.A.; Pavón, J.J.; García-Couce, J.; Galvan, J.C.; García-Moreno, F.; Torres, Y. Improvement of the balance between a reduced stress shielding and bone ingrowth by bioactive coatings onto porous titanium substrates. Surf. Coat. Technol. 2018, 338, 32-37. [CrossRef]

15. Esen, Z.; Bor, Ş. Processing of titanium foams using magnesium spacer particles. Scr. Mater. 2007, 56, 341-344. [CrossRef]

16. Vlacic-Zischke, J.; Hamle, S.M.; Friis, T.; Tonetti, M.S.; Ivanovski, S. The influence of surface microroughness and hydrophilicity of titanium on the up-regulation of TGF $\beta / B M P$ signalling in osteoblasts. Biomaterials 2011, 32, 665-671. [CrossRef] [PubMed]

17. Civantos, A.; Martinez-Campos, E.; Ramos, V.; Elvira, C.; Gallardo, A.; Abarrategi, A. Titanium coatings and surface modifications: Toward clinically useful bioactive implants. ACS Biomater. Sci. Eng. 2017, 3, 1245-1261. [CrossRef]

18. Gristina, A.G. Biomaterial-centered infection: Microbial adhesion versus tissue integration. Science 1987, 237, 1588-1595. [CrossRef]

19. Neoh, K.G.; Hu, X.; Zheng, D.; Kang, E.T. Balancing osteoblast functions and bacterial adhesion on functionalized titanium surfaces. Biomaterials 2012, 33, 2813-2822. [CrossRef]

20. Tuson, H.H.; Auer, G.K.; Renner, L.D.; Hasebe, M.; Tropini, C.; Salick, M.; Weibel, D.B. Measuring the stiffness of bacterial cells from growth rates in hydrogels of tunable elasticity. Mol. Microbiol. 2012, 84, 874-891. [CrossRef] 
21. Dominguez-Trujillo, C.; Beltrán, A.M.; Garvi, M.D.; Salazar-Moya, A.; Lebrato, J.; Hickey, D.J.; Rodriguez-Ortiz, J.A.; Kamm, P.H.; Lebrato, C.; García-Moreno, F.; et al. Bacterial behavior on coated porous titanium substrate for biomedical applications. Surf. Coat. Technol. 2019, 357, 896-902. [CrossRef]

22. García-Moreno, F.; Fromme, M.; Banhart, J. Real-time X-ray radioscopy on metallic foams using a compact micro-focus source. Adv. Eng. Mater. 2004, 6, 416-420. [CrossRef]

23. AENOR. Water Quality_Detection and Enumeration of Escherichia coli and Coliform Bacteria_Part 1: Membrane Filtration Method; UNE-EN ISO 9308-1:2014; International Organization for Standardization: Geneva, Switzerland, 2014.

24. Sterilization of Medical Devices-Microbiological Methods Part 1: Determination of a Population of Microorganisms on Products; ISO 11737:1:2007; International Organization for Standardization: Geneva, Switzerland, 2017.

25. Grimal, Q.; Haupert, S.; Mitton, D.; Vastel, L.; Laugier, P. Assessment of cortical bone elasticity and strength: Mechanical testing and ultrasound provide complementary data. Med. Eng. Phys. 2009, 31, 1140-1147. [CrossRef] [PubMed]

26. Hasan, J.; Crawford, R.J.; Ivanova, E.P. Antibacterial surfaces: The quest for a new generation of biomaterials. Trends Biotechnol. 2013, 31, 295-304. [CrossRef] [PubMed]

27. St-Pierre, J.P.; Gauthier, M.; Lefebvre, L.P.; Tabrizian, M. Three-dimensional growth of differentiating MC3T3-E1 pre-osteoblasts on porous titanium scaffolds. Biomaterials 2005, 26, 7319-7328. [CrossRef] [PubMed]

28. Murphy, C.M.; O'Brien, F.J. Understanding the effect of mean pore size on cell activity in collagen-glycosaminoglycan scaffolds. Cell Adhes. Migr. 2010, 4, 377-381. [CrossRef] [PubMed]

29. do Prado, R.F.; de Oliveira, F.S.; Nascimento, R.D.; de Vasconcellos, L.M.R.; Carvalho, Y.R.; Cairo, C.A.A. Osteoblast response to porous titanium and biomimetic surface: In vitro analysis. Mater. Sci. Eng. C 2015, 52, 194-203. [CrossRef] [PubMed]

30. Wang, D.; Li, Q.; Xu, M.; Jiang, G.; Zhang, Y.; He, G. A novel approach to fabrication of three-dimensional porous titanium with controllable structure. Mater. Sci. Eng. C 2017, 71, 1046-1051. [CrossRef] [PubMed]

31. Chang, M.C.; Tsai, Y.L.; Liou, E.J.W.; Tang, C.M.; Wang, T.M.; Liu, H.C.; Liao, M.W.; Yeung, S.Y.; Chan, C.P.; Jeng, J.H. Effect of Butyrate on Collagen Expression, Cell Viability, Cell Cycle Progression and Related Proteins Expression of MG-63 Osteoblastic Cells. PLoS ONE 2016, 11, e0165438. [CrossRef] [PubMed]

32. Chen, X.; Zhi, X.; Wang, J.; Su, J.C. RANKL signaling in bone marrow mesenchymal stem cells negatively regulates osteoblastic bone formation. Bone Res. 2018, 6, 34. [CrossRef]

33. Civantos, A.; Domínguez, C.; Pino, R.J.; Setti, G.; Pavon, J.J.; Martínez-Campos, E.; Garcia-Garcia, F.J.; Rodriguez-Ortiz, J.A.; Allain, J.P.; Torres, Y. Designing bioactive porous titanium interfaces to balance mechanical properties and in vitro cells behavior towards increased osseointegration. Surf. Coat. Technol. 2019, 368, 162-174. [CrossRef]

34. Kamada, R.; Tano, F.; Kudoh, F.; Kimura, N.; Chuman, Y.; Osawa, A.; Namba, K.; Tanino, K.; Sakaguchi, K. Effective Cellular Morphology Analysis for Differentiation Processes by a Fluorescent 1,3a,6a-Triazapentalene Derivative Probe in Live Cells. PLoS ONE 2016, 11, e0160625. [CrossRef] [PubMed]

35. Hong, D.; Chen, H.X.; Yu, H.Q.; Liang, Y.; Wang, C.; Lian, Q.Q.; Deng, H.T.; Ge, R.S. Morphological and proteomic analysis of early stage of osteoblast differentiation in osteoblastic progenitor cells. Exp. Cell Res. 2010, 316, 2291-2300. [CrossRef] [PubMed]

(C) 2019 by the authors. Licensee MDPI, Basel, Switzerland. This article is an open access article distributed under the terms and conditions of the Creative Commons Attribution (CC BY) license (http://creativecommons.org/licenses/by/4.0/). 